\title{
Hubungan Karakteristik Responden, Daya Beli dan Asal Suku Bangsa dengan Pola Asuh dalam Pemberian Makanan Pendamping Air Susu (MPASI) pada Bayi Usia 0-12 Bulan di Kota Jambi
}

\author{
Reni Mitrasari ${ }^{1}$, Nur Alam Fajar ${ }^{2}$, Zulkarnain $^{3}$ \\ ${ }^{1,2,3}$ Universitas Sriwijaya \\ Correspondence email: renimitrasari@gmail.com
}

\begin{abstract}
Abstrak. Penelitian ini bertujuan Untuk menganalisis hubungan karakteristik responden, daya beli dan asal suku bangsa dengan pola asuh dalam pemberian makanan pendamping air susu (MPASI) pada bayi usia 0-12 bulan di Kota Jambi. Penelitian ini menggunakan metode merupakan penelitian observasional dengan metode penelitian mixed method antara penelitian kualitatif dan kuantitatif. Penelitian ini dilakukan di beberapa suku yang ada di Kota Jambi, seperti Suku Asal Jambi adapun hasil Penelitian adalah Karakteristik responden yaitu ibu yang memiliki pendidikan terakhir rendah sebanyak 38 orang (39,6\%), pengetahuan tentang MPASI kurang baik sebanyak 66 orang $(68,8 \%)$, kebiasan suku (kebiasaan MPASI) kurang baik sebanyak 45 orang (46,9\%), tidak bekerja sebanyak 77 orang $(80,2 \%)$ dan pola asuh MPASI kurang baik sebanyak 50 orang $(52,1 \%)$.
\end{abstract}

Kata kunci: Pola Asuh; Penidikan; Pengetahuan; Suku; Pekerjaan; Daya Beli

\begin{abstract}
This research aims to analyze the relationship characteristic of respondents, purchasing power and the origin of ethnic groups with the foster pattern in the feeding of milk escort food (MPASI) in infants aged 0-12 months in Jambi city. This research using methods is an observational research with a mixed method research method between qualitative and quantitative research. This research was conducted in several tribes in Jambi city, such as the people of Origin Jambi as the result of the research is characteristic of respondents who have a last education low of 38 people (39.6\%), knowledge of MPASI less well as 66 people (68.8\%), customs habits (MPASI) less good as many as 45 people (46.9\%), not working as much as 77 people (And the foster pattern of poor MPASI as much as 50 people (52.1\%).
\end{abstract}

Keywords: Parenting; blowing; knowledge; ethnicity; occupation; purchasing power

\section{PENDAHULUAN}

Masalah gizi adalah hal yang sangat penting dan mendasar bagi kehidupan manusia. Kekurangan gizi selain dapat menimbulkan masalah kesehatan (morbiditas, mortalitas dan disabilitas), juga menurunkan kualitas sumber daya manusia (SDM) suatu bangsa. Dalam skala yang lebih luas, kekurangan gizi dapat menjadi ancaman bagi ketahanan dan kelangsungan hidup suatu bangsa (Depkes RI, 2013).

Keberhasilan pemberian makanan pendamping ASI (MP-ASI) tidak bisa terlepas dari etnik yang ada di suatu masyarakat. Menurut Mead perilaku individu itu ditentukan dari internalisasi perilaku-perilaku sebelumnya yang dilihat dan atau dialami oleh individu dari orang tuanya (significant other) dan dari masyarakatnya (generalized other). Berdasarkan hasil penelitian pada etnik Bugis, menyimpulkan bahwa semua perilaku ibu di Pekkae mulai dari masa hamil sampai anak lahir, proses menyusui dan pemberian makan, tidak terlepas dari ininnawamadeceng (harapan yang baik) kepada anak, sehingga untuk merubah perilaku yang membahayakan kesehatan bayi (prelaktal feeding) tidaklah mudah, karena terkait dengan nilai normative budaya suku masyarakat Bugis (Ismi, dkk, 2013).

Untuk mencapai tumbuh kembang optimal, didalam Global Strategy for Infant and Young Child
Feeding, WHO/UNICEF merekomendasikan empat hal penting yang harus dilakukan, yaitu pertama, memberikan air susu ibu kepada bayi segera dalam waktu 30 menit setelah bayi lahir; kedua, memberikan hanya air susu ibu (ASI) saja atau pemberian ASI secara eksklusif sejak lahir sampai bayi berusia 6 bulan; ketiga, memberikan makanan pendamping air susu ibu (MPASI) sejak bayi berusia 6 bulan sampai 24 bulan; dan keempat, meneruskan pemberian ASI sampai anak berusia 24 bulan atau lebih. Rekomendasi tersebut menekankan, secara social budaya MPASI hendaknya dibuat dari bahan pangan yang murah dan mudah diperoleh di daerah setempat (indigenous food) (Depkes RI, 2006).

Rekomendasi WHO/UNICEF di atas sejalan dengan Rencana Pembangunan Jangka Panjang dan Menengah Nasional (RPJPMN) bidang Kesehatan, antara lain dengan memberikan prioritas kepada perbaikan kesehatan dan gizi bayi dan anak. Sebagai tindak lanjut RPJPMN, Rencana Aksi Nasional (RAN) Pencegahan dan Penanggulangan Gizi Buruk Tahun 2005 - 2009 telah menyusun sejumlah kegiatan yang segera dilaksanakan. Seluruh perbaikan gizi yang dilakukan diharapkan dapat menurunkan masalah gizi kurang dari $27,3 \%$ tahun 2003 menjadi $20 \%$ pada tahun 2009, dan masalah gizi buruk dari 8,0 \% tahun 2003 menjadi $5 \%$ pada tahun 2009 (Depkes RI, 2006). 
Reni Mitrasari et al, Hubungan Karakteristik Responden, Daya Beli dan Asal Suku Bangsa dengan Pola Asuh dalam Pemberian Makanan Pendamping Air Susu (MPASI) pada Bayi Usia 0-12 Bulan di Kota Jambi

Untuk mencapai target di atas, dilakukan sejumlah kegiatan yang bertumpu kepada perubahan perilaku dengan cara mewujudkan Keluarga Sadar Gizi (Kadarzi). Melalui penerapan perilaku Keluarga Sadar Gizi, keluarga didorong untuk memberikan ASI eksklusif pada bayi sejak lahir sampai berusia 6 bulan dan memberikan MP-ASI yang cukup dan bermutu kepada bayi dan anak usia 6-24 bulan. Bagi keluarga mampu, pemberian MP-ASI yang cukup dan bermutu relative tidak bermasalah. Pada keluarga miskin, pendapatan yang rendah menimbulkan keterbatasan pangan di rumah tangga yang berlanjut kepada rendahnya jumlah dan mutu MP-ASI yang diberikan kepada bayi dan anak (Depkes RI, 2006).

Berdasarkan Profil Kesehatan Kota Jambi Tahun 2018 diketahui bahwa kasus gizi buruk masih ditemukan sebanyak 21 orang, tertinggi ditemukan di wilayah kerja Puskesmas Simpang Kawat sebanyak 3 kasus. Dari semua kasus gizi buruk yang ada semuanya telah mendapatkan penanganan dan telah memenuhi target standar pelayanan minimum yaitu $100 \%$. Kasus balita dengan status gizi kurang di Kota Jambi tahun 2018 sebanyak 232 balita, dimana angka tertinggi terdapat di wilayah Puskesmas Pal V sebanyak 22 kasus $(1,7 \%)$. Sementara Untuk bayi dan balita yang mengalami gizi lebih sebanyak 82 orang $(0,3 \%)$, dimana angka tertinggi terdapat diwilayah Puskesmas Kebun Hadil. Hal ini menunjukkan surveilens gizi di Kota Jambi sudah berjalan baik sehingga semua balita yang mengalami masalah gizi dapat tedata dan terpantau (Dinkes Kota Jambi, 2019).

Beberapa penelitian menyatakan bahwa masalah gizi pada bayi dan anak disebabkan kebiasaan pemberian ASI dan MP-ASI yang tidak tepat (segi kuantitas dan kualitas). Selain itu, para ibu kurang menyadari bahwa sejak bayi berusia 6 bulan sudah memerlukan MP-ASI dalam jumlah dan mutu yang baik (Hermina \& Nurfi, 2010).

Adanya perbedaan dan kepercayaan adat istiadat dari masing-masing suku tentang cara pemberian MP ASI selain itu masih terjadinya Kasus gizi buruk dikawasan perkotaan khususnya Kota Jambi yang mana akses transportasi begitu lancar, fasilitas kesehatan sudah tersedia dimana-mana dan tempat pembelian bahan makanan MP ASI seperti pasar tradisional dan pasar modern sudah sangat banyak mendorong adanya penelitian mengenai pola pemberian MP ASI pada 5 suku terbesar yang ada di Kota Jambi yaitu Suku Asal Jambi, Jawa, Minangkabau, Batak dan Palembang. Berdasarkan uraian diatas peneliti tertarik untuk meneliti "Hubungan Karakteristik Responden, Daya Beli Dan Asal Suku Bangsa Dengan Pola Asuh Dalam Pemberian Makanan Pendamping Air Susu (MPASI) Pada Bayi Usia 0-12 Bulan Di Kota Jambi”.

Tujuan dari penelitian ini yaitu untuk menganalisis hubungan karakteristik responden, daya beli dan asal suku bangsa dengan pola asuh dalam pemberian makanan pendamping air susu (MPASI) pada bayi usia 0-12 bulan di Kota Jambi.

\section{METODE}

Penelitian ini merupakan penelitian observasional dengan metode penelitian mixed method antara penelitian kualitatif dan kuantitatif. Desain penelitian yang digunakan adalah desain cross-sectional, yaitu penelitian dengan pengukuran variabel bebas dan terikat dilakukan saat bersamaan (Azwar \& Prihartono, 2003).

\section{Populasi dan Sampel}

Penelitian ini dilakukan di beberapa suku yang ada di Kota Jambi, seperti Suku Asal Jambi (Responden yang berasal dari suku yang ada di $11 \mathrm{Kab} /$ Kota yang ada di Provinsi Jambi dan berdomisili di Kota Jambi), Jawa, Minangkabau, Batak dan Lampung. Populasi adalah seluruh ibu yang memiliki bayi usia 0-12 bulan sebanyak 23.579 orang (BPS Provinsi Jambi Tahun 2019).

\section{Metode Analisis Data}

$$
\mathrm{n}=\frac{\mathrm{Z}^{2}}{\mathrm{~d}^{2}-\alpha / 2 \cdot \mathrm{P} \cdot(1-\mathrm{P}) \cdot \mathrm{N}}
$$

Keterangan :

$$
\mathrm{n} \quad=\text { Jumlah sampel }
$$

$\mathrm{N} \quad=$ Jumlah populasi (23.579)

Z $1-\alpha / 2=$ Nilai derajat kepercayaan $95 \%$ adalah 1,96

$\mathrm{P} \quad=$ Proporsi dari opulasi yang ditetapkan $(0,5)$

$\mathrm{D}=$ Tingkat absolut yang diinginkan $10 \%(0,1)$

Berdasarkan populasi, jumlah sampel yang diperlukan adalah :

$$
\begin{aligned}
\mathrm{n} \quad & =\frac{\mathrm{Z}^{2} 1-\alpha / 2 \cdot \mathrm{P} \cdot(1-\mathrm{P}) \cdot \mathrm{N}}{\mathrm{d}^{2}(\mathrm{~N}-1)+\mathrm{Z}^{2} 1-\alpha / 2 \cdot \mathrm{P} .(1-\mathrm{P})} \\
& =\frac{1,96^{2} \times 0,5 \times 0,5 \times 23 \cdot 579}{0,1^{2}(23 \cdot 579-1)+1,96^{2} \times 0,5 \times(0,5)} \\
& =95,7 \\
& =96
\end{aligned}
$$

\section{HASIL DAN PEMBAHASAN}

Hubungan antara pengetahuan dengan pola asuh dalam pemberian makanan pendamping air susu (MPASI) pada bayi usia 0-12 bulan di Kota Jambi.

Variabel pengetahuan dikelompokkan menjadi 2 kategori yaitu Kurang baik jika jawaban benar $<76 \%$ dari total pertanyaan, Baik jika jawaban benar $\geq 76 \%$ dari total pertanyaan.

Dari hasil penelitian diketahui bahwa dari 66 responden dengan pengetahuan yang kurang baik memiliki pola asuh MPASI yang kurang baik sebanyak 42 orang $(63,6 \%)$ dan memiliki pola asuh MPASI yang baik sebanyak 24 orang (36,4\%). Sedangkan dari 30 responden dengan pengetahuan yang baik memiliki pola asuh MPASI kurang baik sebanyak 8 orang $(26,7 \%)$ dan memiliki pola asuh MPASI yang baik sebanyak 22 orang $(73,3 \%)$. 
Menurut Sumardiono (2007) pada kelompok ibu yang berpengetahuan kurang dalam pemberian makanan pendamping kepada bayinya pada usia 2 bulan, pada kelompok ibu yang berpengetahuan cukup memberikan makanan pendamping pada bayinya pada usia 3-5 bulan, sedangkan pada ibu yang berpengetahuan baik memberikan makanan pendamping pada bayinya setelah berusia lebih dari 6 bulan.

Hasil penelitian ini sejalan dengan hasil penelitian Sri Yulianti (2015) yang menunjukan bahwa ada hubungan pengetahuan ibu dengan pemberian MPASI dini nilai $P$-Value 0,024 .

\section{Hubungan antara suku (Kebiasaan MPASI) dengan pola asuh dalam pemberian makanan pendamping air susu (MPASI) pada bayi usia 0-12 bulan di Kota Jambi.}

Variabel suku (Kebiasaan MPASI) dikelompokkan menjadi 2 kategori yaitu Kurang baik jika jawaban responden $<$ median $(7,00)$, Baik jika jawaban responden $\geq$ median $(7,00)$ dari total pertanyaan.

Dari hasil penelitian diketahui bahwa dari 45 responden dengan kebiasaan MPASI yang kurang baik memiliki pola asuh MPASI yang kurang baik sebanyak 42 orang $(93,3 \%)$ dan memiliki pola asuh MPASI yang baik sebanyak 3 orang (6,7\%). Sedangkan dari 51 responden dengan kebiasaan MPASI yang baik memiliki pola asuh MPASI kurang baik sebanyak 8 orang $(15,7 \%)$ dan memiliki pola asuh MPASI yang baik sebanyak 43 orang $(84,3 \%)$.

Dukungan keluarga dan kebiasaan memberi makan bayi memiliki pengaruh yang signifikan terhadap pemberian makanan pada bayi. Peran keluarga dalam pemberian MPASI > 6 bulan sangat dibutuhkan, terlebih kultur masyarakat Indonesia yang masih bersifat kolektif, yaitu keluarga berperan dalam pola pengurusan anak khususnya dalam pengurusan bayi. Dalam keluarga yang bersifat paternalistik, keluarga yang bertanggung jawab dalam pengurusan bayi adalah para perempuan dari anggota keluarga yang memiliki bayi (Sumardiono, 2007).

Hasil penelitian ini sejalan dengan hasil penelitia Ning Suwarsih (2016) yang menunjukan bahwa uji tabel silang dalam penelitian ini menggunakan tabel $2 \times 2$ namun hasil sel yang nilai expected-nya kurang dari 5 ada $25 \%$ jumlah cell. Hasil ini tidak layak untuk diuji dengan uji Chi-Square oleh karena itu peneliti menggunakan uji alternatif Fisher Exact dan menghasilkan nilai $\mathrm{p}=0,000<(\alpha=0,05)$, $\mathrm{p}$ value lebih kecil daripada nilai $\alpha$. Karena nilai $\mathrm{p}<0,05$ maka pada penelitian ini hipotesis alternatif (H1) diterima dengan kesimpulan ada hubungan antara kepatuhan budaya dengan waktu pemberian makanan pendamping ASI di Desa Peniron Kecamatan Pejagoan Kabupaten Kebumen.
Hubungan antara pekerjaan dengan pola asuh dalam pemberian makanan pendamping air susu (MPASI) pada bayi usia 0-12 bulan di Kota Jambi.

Variabel pekerjaan dikelompokkan menjadi 2 kategori yaitu bekerja dan tidak bekerja.

Dari hasil penelitian diketahui bahwa dari 77 responden yang tidak bekerja memiliki pola asuh MPASI yang kurang baik sebanyak 42 orang $(54,5 \%)$ dan memiliki pola asuh MPASI yang baik sebanyak 35 orang $(45,5 \%)$. Sedangkan dari 19 responden dengan yang tidak bekerja memiliki pola asuh MPASI yang kurang baik sebanyak 8 orang $(42,1 \%)$ dan memiliki pola asuh MPASI yang baik sebanyak 11 orang $(57,9 \%)$. Hasil uji statistik diperoleh $p$-value $=0,474$ ( $p$-value $>$ $0,05)$, sehingga dapat disimpulkan bahwa tidak ada hubungan yang bermakna antara pekerjaan dengan pola asuh dalam pemberian makanan pendamping air susu (MPASI).

Menurut Suroto (1992) "Pekerjaan adalah setiap kegiatan yang menghasilkan barang atau jasa bagi diri atau orang lain, baik orang yang melakukan dibayar atau tidak". Pekerjaan adalah kegiatan yang menghasilkan barang atau jasa bagi diri sendiri atau orang lain dalam kurun waktu tertentu. Setiap kegiatan manusia yang menghasilkan barang atau jasa dalam kurun waktu tertentu dapat dimaknai sebagai pekerjaan, tetapi tidak semua pekerjaan dapat menghasilkan imbalan atau bayaran. Suatu kegiatan dapat dikatakan sebagai pekerjaan apabila terdapat tanggungjawab yang menyertai kegiatan itu. Pekerjaan mensyaratkan tanggung jawab yang harus dilaksanakan dalam kurun waktu tertentu.

Hubungan antara daya beli dengan pola asuh dalam pemberian makanan pendamping air susu (MPASI) pada bayi usia 0-12 bulan di Kota Jambi.

Variabel daya beli dikelompokkan menjadi 2 kategori yaitu kurang baik jika < Upah Minimum Provinsi Jambi (Rp2.423.888) dan jumlah anggota keluarga $>4$ orang, Baik jika $\geq$ Upah Minimum Provinsi Jambi (Rp2.423.888)dan jumlah anggota keluarga $\leq 4$ orang.

Dari hasil penelitian diketahui bahwa dari 43 responden dengan daya beli yang kurang baik memiliki pola asuh MPASI yang kurang baik sebanyak 43 orang $(67,4 \%)$ dan memiliki pola asuh MPASI yang baik sebanyak 14 orang (32,6\%). Sedangkan dari 53 responden dengan daya beli yang baik memiliki pola asuh MPASI kurang baik sebanyak 21 orang $(39,6 \%)$ dan memiliki pola asuh MPASI yang baik sebanyak 32 orang $(60,4 \%)$.

Hal ini sesuai dengan hasil penelitian Sri Yuluanti (2015) penelitian di lapangan bahwa pendapatan memungkinkan ibu untuk memberikan makanan tambahan bagi bayi usia $<6$ bulan. Makin baik perekonomian keluarga, maka daya beli makanan tambahan akan semakin mudah. Hal ini sesuai dengan 
pernyataan Nauli (2012) yang menyatakan bahwa pendapatan memungkinkan ibu untuk memberikan makanan tambahan bagi bayi usia kurang dari enam bulan, semakin baik perekonomian keluarga maka daya beli akan makanan tambahan juga mudah, sebaliknya semakin buruk perekonomian keluarga, maka daya beli akan makanan tambahan lebih sukar. Tingkat penghasilan keluarga berhubungan dengan pemberian MP-ASI dini

\section{SIMPULAN}

Dari hasil penelitian dan pembahasan ada beberapa hal dapat disimpulkan, yaitu:

1. Karakteristik responden yaitu ibu yang memiliki pendidikan terakhir rendah sebanyak 38 orang (39,6\%), pengetahuan tentang MPASI kurang baik sebanyak 66 orang $(68,8 \%)$, kebiasan suku (kebiasaan MPASI) kurang baik sebanyak 45 orang (46,9\%), tidak bekerja sebanyak 77 orang $(80,2 \%)$ dan pola asuh MPASI kurang baik sebanyak 50 orang $(52,1 \%)$.

2. Ada hubungan yang bermakna antara pengetahuan dengan pola asuh dalam pemberian makanan pendamping air susu (MPASI) pada bayi usia $0-12$ bulan $(p$-value $=0,002)$ dan OR 4,813 $(1,857$ 12,469).

3. Ada hubungan yang bermakna antara suku (kebiasaan MPASI) dengan pola asuh dalam pemberian makanan pendamping air susu (MPASI) pada bayi usia $0-12$ bulan $(p$-value $=0,000)$ dan OR 75,250 $(18,680-$ 303,136).

4. Tidak ada hubungan yang bermakna antara pekerjaan dengan pola asuh dalam pemberian makanan pendamping air susu (MPASI) pada bayi usia $0-12$ bulan $(p$-value $=0,474)$.

5. Ada hubungan yang bermakna antara daya beli dengan pola asuh dalam pemberian makanan pendamping air susu (MPASI) pada bayi usia $0-12$ bulan $(p$-value $=0,012)$ dan OR 3,156 $(1,359-7,330)$.

\section{DAFTAR PUSTAKA}

Azwar, A., \&Prihartono, J. 2003. Metodologi Penelitian Kedokteran dan Kesehatan Masyarakat. Batam: Binarupa Aksara.

BPS Kota Jambi, 2019. Data Statistik Penduduk Kota Jambi Tahun 2018. Kota Jambi

Depkes RI. 2000. Makanan Pendamping Air Susu Ibu, Jakarta

2006. Pedoman Umum Pemberian Makanan Pendamping Air Susu Ibu (MP-ASI). Jakarta.

2013. Masalah Gizi di Indonesia. http://www.depkes.go.id/reso urces/ download Ipusdatin/profil-kesehatan-

indonesia/profilkesehatan-indonesia 2013. pdf. Diakses : 05 Agustus 2019.

Dinkes Kota Jambi. 2019. ProfilKesehatan Kota Jambi Tahun 2018. Kota Jambi
Hermina..\&Nurfi. 2010. Hubungan Praktik Pemberian Asi Eksklusif Dengan Karakteristik Sosial. Demografi Dan Faktor Informasi Tentang ASI Dan MP-ASI (Studi Di Kota Padang Dan Kabupaten Solok Provinsi Sumatera Barat). Pusat Penelitian dan Pengembangan Gizi dan Makanan. Badan Litbang Kesehatan. Kementerian Kesehatan

Ismi, dkk. 2013. Pola Asuh Pemberian Makanan Pendamping ASI (MP-ASI) Pada Ibu Baduta Di Tanah Adat Kajang Ammatoa Kabupaten Bulu kumba. Sulawesi Selatan

Sumardiono. 2007. Hubungan pengetahuan dan sikap ibu dengan pemberian MPASI di kelurahan PB. Selayang 